\title{
BEHIND THE FACADE OF UVAROV'S CLASSICISM: CAREER STRATEGIES OF CLASSICAL PHILOLOGISTS AT RUSSIAN UNIVERSITIES ${ }^{1}$
}

\author{
Kira A. Ilina \\ National Research University "Higher School of Economics", Moscow, Russian Federation
}

\begin{abstract}
Introduction. The article is focused on reconstruction of the practices of forming a disciplinary group of classical philologists in the Russian Empire universities in the 1830s-1850s. Methods. For this purpose, the archival materials of the Ministry of Education, as well as Saint Petersburg, Moscow, Kazan and Kiev Universities are considered. The research methodology is based on a combination of both traditional general historical methods and methods of classical source studies, and approaches developed in the framework of the history of science, the sociology of knowledge and the history of disciplines. Analysis and results. It is important to analyze three points: the political context, practices in building career trajectories and academic networks of professors of Greek and Roman literature and antiquities at Russian universities. The transformation of the existing network of universities into the system of public education was carried out by the Minister of Public Education Sergey Uvarov in the 1830s. Transferring to Russia the European model of secondary education based on the study of classical languages, Uvarov created a system of general education and relentlessly promoted antiquity studies in the Russian Empire. Teaching classical disciplines was expanded at gymnasiums and universities. Following the academic personnel reform of the late 1830s, a number of "antiquity chairs" at universities was headed by young philologists and historians who had spent two or three years of training at universities in Germany, mainly in Berlin, attending lectures and seminars of leading German classical philologists. In the 1840s - 1850s, an artificially constructed group of classical philologists gradually transformed into a disciplinary community.
\end{abstract}

Key words: Russian Empire, universities, classical philology, professor, Sergey Uvarov.

Citation. Ilina K.A. Behind the Facade of Uvarov's Classicism: Career Strategies of Classical Philologists at Russian Universities. Vestnik Volgogradskogo gosudarstvennogo universiteta. Seriya 4. Istoriya. Regionovedenie. Mezhdunarodnye otnosheniya [Science Journal of Volgograd State University. History. Area Studies. International Relations], 2020, vol. 25, no. 2, pp. 80-92. (in Russian). DOI: https://doi.org/10.15688/jvolsu4.2020.2.6

УДК 94(47).073

Дата поступления статьи: 30.01.2020

ББК 63.3(2)521

Дата принятия статьи: 06.03.2020

\section{ЗА ФАСАДОМ УВАРОВСКОГО КЛАССИЦИЗМА: КАРЬЕРНЫЕ СТРАТЕГИИ ФИЛОЛОГОВ-КЛАССИКОВ В УНИВЕРСИТЕТАХ РОССИЙСКОЙ ИМПЕРИИ ${ }^{1}$}

\section{Кира Андреевна Ильина}

Национальный исследовательский университет «Высшая школа экономики», г. Москва, Российская Федерация

Аннотация. В статье реконструируются практики формирования дисциплинарной группы филологовклассиков в Российской империи 1830-1850-х годов. Источниковой основой исследования являются делопроизводственные материалы, извлеченные из фонда Департамента народного просвещения и университетских фондов российских и зарубежных архивов. Методология исследования строилась на сочетании как традиционных общеисторических методов и методов классического источниковедения, так и подходов, разработанных в рамках истории науки, социологии знания и истории дисциплин. Для анализа важно изучение трех аспектов: политического контекста формирования сообщества филологов-классиков и классической филологии как университетской дисциплины, практик построения карьерных траекторий и академических 
сетей профессоров греческой и латинской словесности и древностей в российских университетах. Преобразование существующей сети университетов в систему народного образования было проведено министром народного просвещения С.С. Уваровым в первой половине 1830-х годов. Он говорил о русских университетах как о национальных институциях, ожидал от русских университетов производства русской науки. В то же время С.С. Уваров, ученый-эллинист, воспринял идею Фридриха Вольфа о связи классической филологии с воспитанием нации и национальной элиты. Она отразилась в инициативе министра народного просвещения по созданию в России системы общего образования, основанной на изучении классического наследия, расширению преподавания классических дисциплин в гимназиях и университетах. Преобразование университетов сопровождалось масштабной кадровой реформой, в результате которой университетские кафедры заняли молодые ученые-классики, познакомившиеся во время стажировок в немецких университетах с новейшими достижениями классической филологии. На протяжении 1840-1850-х гг. искусственно сконструированная группа филологов-классиков постепенно трансформируется в дисциплинарное сообщество.

Ключевые слова: Российская империя, университеты, классическая филология, профессор, С.С. Уваров.

Цитирование. Ильина К. А. За фасадом уваровского классицизма: карьерные стратегии филологовклассиков в университетах Российской империи // Вестник Волгоградского государственного университета. Серия 4, История. Регионоведение. Международные отношения. - 2020. - T. 25, № 2. - С. 80-92. - DOI: https:// doi.org/10.15688/jvolsu4.2020.2.6

Введение. Современными исследователями университет и система высшего образования рассматриваются как социальная основа дисциплинарного деления. Дисциплинарные структуры формируются и изменяются действиями ученых, а университет является тем местом, где проговариваются и устанавливаются границы дисциплин. Поэтому важным становится изучение практик (само)организации дисциплин, способов создания и трансформации внутренних иерархий, складывания разделенного контекста об авторитетах, конфликтах. В данной статье в центре внимания - механизмы и практики формирования дисциплинарной группы филологов-классиков в Российской империи николаевского царствования и роль разных акторов (министра, чиновников Министерства народного просвещения, профессоров) в этом процессе.

Исследователями образования и науки изучены вопросы, связанные с институциональными, социальными и культурными изменениями в сфере просвещения, выявлена роль министра народного просвещения С.С. Уварова в развитии классического образования и классицизма в России, рассмотрена проблема «русской античности», способов ее проживания в культуре, а также восприятия Николаем I, чиновниками, отдельными интеллектуалами. Есть работы, посвященные изучению вклада историков в изучение антиковедения (см., например, работы Э.Д. Фролова, А.М. Скворцова, Ф.А. Петрова), но становление и развитие классической филологии за- частую остается зоной умолчания. Упоминания о филологах-классиках в работах по истории университетов и разрозненные исторические справки об их исследованиях в специализированных или юбилейных университетских биографических словарях не позволяют составить представление о развитии классической филологии в России, соотношении замысла законодателя и его воплощения в реальности, причинах и обстоятельствах изменения ее статуса, а также условиях и механизмах формирования и функционирования профессионального сообщества в рамках этой дисциплины.

Методы и материалы. Источниковой основой исследования являются делопроизводственные материалы, извлеченные из фонда Департамента народного просвещения (Российский государственный исторический архив), а также документы из университетских фондов российских (Центральный государственный исторический архив Санкт-Петербурга, Центральный государственный архив города Москвы, Государственный архив Республики Татарстан) и зарубежных архивов (Центральный государственный исторический архив Украины (г. Киев), Государственный архив г. Киева). В многообразных делопроизводственных документах, включающих прошения о занятии должностей, рекомендательные письма, протоколы заседаний факультетов, отчеты, инструкции и исходящих от министра, чиновников министерства, советов университетов и отдельных профес- 
соров, зафиксированы актуальные, не отредактированные временем (как, например, в мемуарах) критерии допуска в сообщество, а также отражен процесс их формулирования на разных уровнях. Методология исследования построена на сочетании как традиционных общеисторических методов и методов классического источниковедения, так и подходов, разработанных в рамках истории науки, социологии знания, истории идей и истории дисциплин.

Анализ. Политический контекст. Сегодня под классической филологией понимают изучение античной литературы, древнегреческого и латинского языков. Однако для конца XVIII - XIX в. под этим термином подразумевался комплекс дисциплин: от грамматики, литературы и всемирной истории до мифологии, географии и истории искусства. В 1780-е гг. немецкий филолог-классик Фридрих Вольф сформулировал идею классической филологии как всеобъемлющего знания об античности. В начале XIX в. классическая филология в Германии профессионализировалась. Этот процесс сопровождался жаркими диспутами о том, чем должны заниматься представители данной науки. В итоге сложилось два направления изучения классической филологии: критико-грамматическое и историческое («филология слов» и «филология вещей») $[5 ; 15 ; 29 ; 31]$.

К 30-м гг. XIX столетия исследователи относят превращение любительского интереса и увлеченности античностью в Российской империи, характерных для второй половины XVIII начала XIX в., в научное направление и университетскую дисциплину. Эта перемена историками науки связывается с археологическими открытиями на юге империи, трансфером в Россию приемов и методов немецкой классической филологии и философии, а также с деятельностью президента Академии наук и министра народного просвещения С.С. Уварова [3; 4, с. $167-$ $168 ; 33 ; 34 ; 36]$.

Ученый-эллинист С.С. Уваров воспринял политический аспект концепции Ф. Вольфа о связи классической филологии с воспитанием нации и национальной элиты. Так, создание в России (по аналогии с Европой) системы общего образования, основанной на изучении классического наследия, и расши- рение преподавания классических дисциплин в гимназиях и университетах соседствовали с высказываниями министра о русских университетах как национальных институциях и с ожиданием от русских университетов производства русской науки, а от преподавателей - лояльности и продвижения государственной идеологии [32].

Вектор политического отношения к классической филологии и изучению древних языков изменился после революций 1848-1849 годов. Правительственные круги Пруссии и России считали, что одной из причин революций являлось классическое образование, которое вредно влияет на молодежь, воспитывая демократические идеалы. Преподавание греческого языка было решено сократить и оставить только в университетах и некоторых гимназиях. В 1852 г. П.А. Ширинский-Шихматов, сменивший С.С. Уварова на посту министра народного просвещения, добился запрета в высших и средних учебных заведениях эразмовского произношения и вернул принятое в православных духовных академиях и семинариях рейхлиново произношение [30].

Чувствуя смену политического курса уже в начале 1851 г., адъюнкт Санкт-Петербургского университета Иван Штейнман в своей торжественной речи, посвященной месту древней филологии среди университетских дисциплин, высказал мысль о пользе сравнительного языкознания и связи греческого языка с русским, а также классической филологии как науке, «органически связанной с исследованиями Отечественного языка» [35, c. 198]. Он писал, что «наука древности сошлась с наукой славянскою», «греческий и латинский языки важны и необходимы для успешного исследования Славянских наречий» [35, с. 198]. То есть идея общеевропейской базы уже не актуальна, актуально - национальное, «славянское». Интересно, что в 1854 г. этот же аргумент (о родстве языков) использовал другой адъюнкт, Борис Ордынский, для развития интриги против немецких профессоров-классиков в русских университе$\operatorname{Tax}[12 ; 38]$.

Карьерные траектории. В 1830-е гг. при непосредственном участии С.С. Уварова в университетах империи началось формирование профессионального сообщества фило- 
логов-классиков. В это время проводилась масштабная кадровая реформа [14], целью которой было уволить «профессоров, без заслуг, но без нарекания, опоздалых на их поприще, мало способных к преподаванию, одним словом просто доживающих срок к получению пенсии» [6, л. 87 об.]. Среди них были, например, профессора Харьковского университета: ординарный профессор греческой словесности Эрнст Маурер, имевший, по словам попечителя Ю.А. Головкина, «чрезвычайно странное произношение, производящее даже смех» $[6$, л. 44], и экстраординарный профессор латинского языка и древностей 64-летний Николай Паки-де-Савиньи, которого предлагалось вывести из штата не за профессиональное несоответствие, а «по старости своей, и по недугам ей свойственным» [6, л. 14].

Старых профессоров планировалось заменить молодыми учеными. Для подготовки будущих профессоров российских университетов в конце 1820-х - 1830-е гг. было осуществлено несколько образовательных государственных проектов [23, с. 16-67]. В результате русские университеты получили европейски образованных молодых ученых, защитивших диссертации и готовых занять освобожденные в ходе реформы профессорские кафедры: медиков, юристов, ботаников, зоологов, экономистов, физиков, математиков, историков и филологов. Распределением вернувшихся специалистов по русским университетам занимался лично министр Уваров.

Во второй половине 1830-х гг. целый ряд «античных» кафедр заняли молодые филологи и историки, выпускники первого и второго наборов Дерптского профессорского института, Главного педагогического института, а также отдельные стипендиаты [4, с. 189-190; 13 , c. $175-183 ; 23$, c. $144-153 ; 34$, c. 149-174]. Так, «укомплектованы» молодыми (на момент принятия на кафедру им было по 27-30 лет) уваровскими филологами-классиками были кафедры латинской и греческой словесности в Московском (Дмитрий Крюков и Владимир Печерин) и Харьковском (Альфонс Валицкий и Семен Лукьянович) университетах. Все они прошли двух- или трехлетнюю стажировку в университетах Германии, главным образом в Берлине, слушали лекции и занимались у ведущих немецких филологов-классиков.
В конце 1820-х - первой половине 1830-х гг. важную роль в формировании будущих филологов-классиков играл Дерптский университет (alma mater Федора Фрейтага, Ивана Нейкирха и Александра Дёллена) и организованный на его базе Профессорский институт (где учились Дмитрий Крюков и Альфонс Валицкий). По Уставу 1820 г. классические дисциплины в Дерпте преподавались на двух кафедрах историко-филологического отделения философского факультета: красноречия, древней классической филологии, эстетики и истории художеств; истории литературы, древней классической филологии и педагогики [25, стб. 1382, № 481]. Первую кафедру с самого основания университета и до 1836 гг. занимал филолог и нумизмат Карл Моргенштерн, выпускник Галльского университета и ученик Ф. Вольфа. Ученый занимал профессорскую должность, был директором университетской библиотеки, музея искусств и педагогико-филологической семинарии. Учрежденную в 1820 г. кафедру истории литературы, древней классической филологии и педагогики в 1820 1830 -е гг. занимал выпускник Кильского университета Иоганн Франке, а после его смерти - выпускник Берлинского университета, ученик Августа Бёка Фридрих-Христиан (Фридрих Фридрихович) Нейе [22, с. 86-95].

К. Моргенштерн, И. Франке и Ф.-Х. Нейе (а в 1832 г. и Фрейтаг [8, л. 3 об.] «по частным поручениям» за денежное вознаграждение [10, л. 54]) преподавали воспитанникам Профессорского института классические языки и цикл наук, необходимый для ученыхклассиков: историю греческой и латинской словесности и древностей, археологию изящных искусств, древнюю нумизматику, филологическую энциклопедию и методологию [2; 9]. После смерти профессора И. Франке К. Моргенштерн устраивал для Д. Крюкова и А. Валицкого специальные «латинские диспуты о филологических предметах». По итогам обучения Д. Крюков в 1832 г. и А. Валицкий в 1833 г. защитили докторские диссертации: «Observationes ad Taciti Agricolam» и «De Cornelio Nepote» соответственно.

После этого молодые ученые отправились на стажировку в Берлинский университет, где посещали лекции профессоров А. Бёка, Л.Д. фон Хеннинга, К. Лахмана, И. Бекке- 
pa, Ф.К. фон Савиньи и других, а также принимали «деятельное участие» в организованном А. Бёком филологическом семинаре (по выражению Д. Крюкова, «латинском диспутаториуме»). Русские студенты были очарованы А. Бёком. Молодой кандидат Владимир Печерин, ученик столичного профессора Федора Грефе, присоединенный к воспитанникам Профессорского института, писал в своем отчете министру в 1833 г.: «Лекции Бёка доставили мне полный и ясный образ всех предметов, составляющих круг деятельности филолога. Соглашаясь с знаменитым Вольфом в основной идее филологии как науки древности... г. Бёк опровергает сделанное сим ученым распределение филологических наук и созидает новую систему, строго выведенную из коренной идеи науки» [7, л. 73-73 об.]. Ему вторил и Д. Крюков: «Отрадно было слышать живую речь проф. Бёка, сообщавшего всему, чему касался особенный интерес» [7, л. 87]. Неотъемлемой частью обучения было чтение «филологических журналов, необходимое для того, чтобы следовать за ходом науки» [7, л. 194].

В Санкт-Петербургский университет был переведен 36-летний профессор Одесского Ришельевского лицея Ф. Фрейтаг [37, c. 81-82]. Закончив в 1820 г. Дерптский университет, он 6 лет преподавал в Дерптской гимназии латинский и греческий языки, а затем два года служил цензором в Цензурном комитете в Дерпте [17, л. 2 об. - 3]. После закрытия комитета 1 декабря 1828 г. Ф. Фрейтаг отправился в «ученое путешествие по Германии, Италии до Неаполя, Швейцарии, Франции» [24, л. 4 об.]. Он путешествовал полтора года, и, видимо, в это время защитил в Тюбингене докторскую диссертацию «Antiquitatum Homericarum Specimen I». Вернувшись в Дерпт в 1830 г., преподавал в Дерптском университете и Профессорском институте. Параллельно претендовал на кафедру греческой словесности в Виленском университете [24, л. 4 об.], которая освободилась после смерти профессора Вильгельма Минниха [11]. В 1833 г. был определен профессором греческой и латинской словесности в Ришельевский лицей в Одессе, а и уже через год просил министра определить его профессором в Киев или какой-нибудь другой университет империи. Пер- вое, что разочаровало ученого - это отсутствие научных пособий и справочников, необходимых для планируемой научной деятельности. Сравнивая лицейскую и публичную одесскую библиотеку с гимназическими в Дерптском учебном округе, Ф. Фрейтаг отмечал полную их непригодность для профессиональных занятий филологией и историей. «Лицейская библиотека в филологическом отношении уступает любой гимназической библиотеке в Дерптском учебном округе, - возмущался Ф. Фрейтаг, ее основное преимущество заключается в французских переводах. Публичная городская библиотека... <..> ...Для ученого, который желает заняться филологическими или историческими исследованиями,

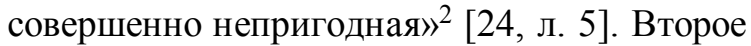
разочарование - низкая подготовка слушателей, которая не давала молодому ученому возможности преподавать на желаемом им уровне. «Я полагал встретить аудиторию студентов, каковую я имел в Дерпте, основательно подготовленную гимназическим образованием критического и грамматического разбора античных авторов на более высоком уровне, писал министру профессор. - Вместо этого я вынужден объяснять своим слушателям, каковые, разумеется, не в том сами не виноваты, самые тривиальные грамматические вещи у Гомера и Горация. Я вынужден совершенно отказаться (от идеи. $-K$. И.) обучить прилежных филологов, даже если они, более подготовленные со временем, будут посещать мои лекции. <...> ...Здесь отдается предпочтение образованию не ученых, а чиновников» [24, л. 5]. Тем не менее дело с определением Ф. Фрейтага в Университет Св. Владимира сначала застопорилось, а потом он сам отказался от предложенной ему экстраординарной кафедры из-за финансовых соображений. Однако министр о просьбе Ф. Фрейтага не забыл, и в 1836 г. он был приглашен в СанктПетербургский университет и на 16 лет занял кафедру римской словесности и древностей.

В конце 1830-х гг. обе кафедры Университета Св. Владимира в Киеве были заняты выпускниками Дерптского университета благодаря протекциям. Так, в 1837 г. на кафедру греческой словесности и древностей был определен 34-летний И. Нейкирх, стажировавшийся в начале 1830-х гг. в университетах 
Германии, Швейцарии и Италии и имевший рекомендации от филолога Готфрида Германа. И. Нейкирх имел степени доктора Лейпцигского университета и магистра Дерптского университета. Через два года 25-летний учитель Рижской гимназии, получивший также только степень магистра, А. Дёллен занял кафедру римской словесности. Немалую роль в этом сыграло покровительство старшего коллеги, который был обязан его отцу, директору гимназии в Митаве Карлу Дёллену. В сентябре 1840 г. И. Нейкирх направил в совет Университета Св. Владимира предложение, в котором утверждал, что молодой ученый, известный ему отличными «филологическими сведениями вообще, так преимущественно сведениями по части римской литературы», будет хорошим преподавателем римской словесности. «Дёллен мне давно уже известен, писал профессор, - как человек с дарованиями и наверное могу сказать, что он, изучая предмет свой, всегда имел столько неутомимого прилежания и столько усердия к изучаемому им предмету, сколько необходимо требуется для приобретения сведений прочных и основательных» [18, л. 1 - 1 об.]. И. Нейкирх обращал внимание на способность своего протеже «самостоятельно обработать» «какую угодно часть своего предмета» и свободное владение латинским языком. Отдельно профессор отмечал «способность ясно и отчетливо передавать свои познания, что составляет необходимую принадлежность хорошего преподавателя» [18, л. 1 об.]. В результате А. Дёллен был утвержден экстраординарным профессором [18, л. 6-9; 20, л. $7-10$ об.]. Другой претендент на кафедру римской словесности, выпускник Харьковского университета, ученик скандально-известного профессора философии Иоганна Шада - 46-летний Илья Гриневич возмущался, что ему предпочли «мальчика Дёллена» [28, с. 132].

В начале 1840-х гг. в Московском и Казанском университетах кафедры греческой словесности и древностей заняли молодые ученые из Германии. В 1837 г. по ходатайству попечителя С.Г. Строганова и рекомендации Ф.Б. Грефе министр С.С. Уваров определил в Московский университет выпускника Кассельской гимназии, Геттингенского и Марбургского университетов, доктора философии Мар- бургского университета Карла Гофмана (18111877) [1, с. 262-263; 16; 23, с. 152]. Тогда московский попечитель (после скандального увольнения В.С. Печерина) искал нового преподавателя греческой словесности. Четыре года К. Гофман преподавал эту дисциплину без платы, пока в 1841 г. не получил звание экстраординарного профессора [21, л. 1 1 об.]. В 1840 г. в Казанский университет по результатам конкурса на кафедру был утвержден Фридрих Фатер (1810-1866?), имеющий рекомендательные письма своего учителя А. Бёка и Александра Гумбольдта. Он был сыном кенигсбергского профессора философии Иоганна Северина Фатера, учился в Берлинском университете и в 1840 г. защитил диссертацию в Галле.

Из «старых» профессоров-классиков после кадровой реформы остались только профессор римской словесности Казанского университета Август Шарбе (1793-1868) и профессор греческой словесности Санкт-Петербургского университета Ф.Б. Грефе (1780-1851). Выпускник Виттенбергского университета А. Шарбе был приглашен в Казанский университет в 1833 г. после рассмотрения его сочинения профессорами. Окончивший Лейпцигский университет ученик Г. Германа Ф.Б. Грефе приехал в Россию в 1810 году. Он стал преподавать в Невской духовной академии, а чуть позднее, познакомившись с попечителем Санкт-Петербургского учебного округа Сергеем Уваровым, занял кафедру греческой словесности в Главном педагогическом институте (с 1819 г. - Санкт-Петербургский университет), с 1820 г. был членом Академии наук.

Так, сформированная разными способами группа филологов-классиков, благодаря сопоставимым образовательным траекториям, обладала разделенным пониманием сущности и содержания классической филологии. Через преподавание, рецензирование докторских и магистерских диссертаций они перенесли в Российскую империю дисциплинарные нормы и соглашения, достигнутые германскими филологами-классиками.

Академические сети. Сконструированная С.С. Уваровым группа филологов-классиков изначально больше представляла собой собрание отдельных ученых, чем научное сообщество. В основном филологи-классики 
были замкнуты в своих университетах или образовывали собственные автономные интеллектуальные сети, обусловленные сценариями академической карьеры.

Например, несмотря на семилетнее совместное обучение Д. Крюкова и А. Валицкого в Дерпте и Берлине, на данный момент не удалось найти свидетельств о поддержании дружеского или профессионального общения после распределения их на кафедры. Тем не менее Д. Крюков не терял связей с немецкими учеными и в начале 1840-х гг. совершил путешествие по Германии и Италии, издал книгу в Лейпциге. Он также успел подготовить ученика - Павла Леонтьева, будущего издателя «Пропилеев». А. Валицкий увлекался нумизматикой и заведовал университетским минц-кабинетом. Столкнувшись с трудностями атрибуции и осознав необходимость консультации с коллегами, он выбил себе командировку по лучшим минц-кабинетам империи (находящимся в Москве, Дерпте и Санкт-Петербурге), а также в столичную Академию художеств с целью обогащения университетского кабинета изящных искусств.

Осознавал необходимость научных командировок, или, как тогда говорили, «путешествий с ученою целию», для налаживая и поддержания научных связей и молодой профессор греческой словесности Казанского университета Ф. Фатер. Он несколько раз ездил в Москву и Санкт-Петербург, познакомился с коллегами в университете и Академии наук (в 1842 г. женился, а в 1846 г. развелся с дочерью академика Христиана Френа), изучил способ преподавания греческого языка и литературы в столичных университетах, ознакомился с музейными коллекциями, поработал с рукописями в библиотеках. При этом в 1840-е гг. активно публиковался в Казани, Москве, Берлине и Лейпциге. В начале 1850 -х гг. Ф. Фатер, ссылаясь на догоняющий характер развития классической филологии в России, обосновывал необходимость своего путешествия в Германию с тем, чтобы возобновить старые и завести новые личные связи с коллегами-филологами из немецких университетов. Однако выстраиванию подобных связей в это время не способствовала политическая ситуация: после революций 1848-1849 гг. были отменены европейские командировки [27, стб. 994, № 861], которые возобновились только с 1856 г.; а 8 мая 1850 г. мнением Государственного совета было аннулировано право университетов и Академии наук выписывать книги и периодические издания без цензурного рассмотрения (возобновлено в 1859 г.) [26, стб. 374, № 198]. Кроме создания горизонтальных профессиональных связей, Ф. Фатер активно выстраивал и вертикальные: воспитывал учеников, возглавив филологический семинар в Казани.

С учетом вышесказанного более чем странным представляется «оседлость» киевских филологов-классиков. И. Нейкирх и А. Дёллен занимали кафедры до конца 1860 -х гг. и не оставили после себя учеников.

Ситуация с налаживанием горизонтальных связей внутри сообщества изменилась в первой половине 1850-х гг., когда подвижки наметились в нескольких сферах. В середине столетия (в условиях научной изоляции) ученик Д. Крюкова П. Леонтьев объединил филологов, историков и археологов для работы над «Пропилеями» - пятью томами сборника статей по классической древности. Поначалу в издании принимали участие профессора Московского университета. Исключением был Николай Благовещенский, товарищ П. Леонтьева по заграничной стажировке, занимавший в начале 1850 -х гг. позиции в Казани, а потом в Санкт-Петербурге. Однако со временем география сборника расширялась: в 1853-1856 гг. свои статьи Леонтьеву прислали министр С.С. Уваров, археологи из Санкт-Петербурга и Одессы, ученые из немецких и некоторых российских университетов (Харьков), Академии наук и Духовной академии. Исследователями из Киева и Казани участие в сборнике было по каким-то причинам проигнорировано.

Еще одним полем, где устанавливались дисциплинарные границы в 1850-1860-е гг. и происходило обсуждение научных достижений, стали историко-литературные журналы («Отечественные записки», «Современник», «Москвитянин») и «Журнал Министерства народного просвещения».

Формированию горизонтальных связей способствовало и постоянное перемещение кандидатов, магистров и докторов из учебных заведений одного округа в другой. Так, в 
1839 г. выпускник Главного педагогического института Арсений Менщиков после стажировки в Берлине воспользовался предложением попечителя Московского учебного округа С.Г. Строганова и перевелся в Москву, где впоследствии и продолжил свою карьеру. Выпускника этого же института Н. Благовещенского после заграничного путешествия министр С.С. Уваров в 1845 г. определил в Казанский университет, а после защит двух диссертаций через семь лет перевел обратно в столицу. Выпускник Дерптского университета Федор Струве, защитивший в 1843 г. в столичном университете магистерскую диссертацию, был приглашен учителем латинского языка в 1-ю Казанскую гимназию, а потом стал преподавать и в университете.

Одним из способов оставить молодых специалистов в университете было определение их на должности адъюнктов. В результате обсуждений и договоренностей одна из двух выделенных по Уставу 1835 г. на историко-филологическое отделение философского факультета адъюнктских ставок была отдана на кафедру римской словесности. Единственным исключением в данном случае стал Казанский университет, где профессор греческой словесности и древностей Ф. Фатер в 1846 г. правдами и неправдами доказывал Совету, а совет попечителю, а попечитель министру, что доктор греческой словесности Клеотильд Тхоржевский, блестящий ученик Ф. Фатера, которого прочили ему в преемники, достоин степени адъюнкта именно по этой специальности. В результате, с 1847 г. Казанский университет имел адъюнктов по двум классическим кафедрам [19]. Таким образом, были расширены институциональные границы дисциплины.

Из-за невозможности оставить всех защищенных кандидатов, магистров и докторов в университете их определяли учителями в гимназии, смотрителями училищ. Однако это не покрывало недостатка в учителях языков, и поэтому профессора и адъюнкты зачастую совмещали службу в университете с преподаванием классических языков в духовных академиях, Академии наук, педагогических институтах, губернских гимназиях, а также с многочисленными административными должностями. В 1830-1850-е филологи-классики становились ректорами (Кронеберг), проректорами (И. Нейкирх) и деканами факультетов (И. Нейкирх, А. Валицкий, Ф. Струве, Ф.Б. Грефе), участвовали в работе разных комиссий, визитациях и т. п.

Результаты. Затеянная Карлом Ливеном кадровая реформа, государственные образовательные программы, подразумевающие стажировку молодых филологов в германских университетах у ведущих филологов-классиков, специализация министра народного просвещения С.С. Уварова как филолога-классика и его ориентация на европейские образцы при проведении собственных реформ, а также профессиональные и личные связи министра и профессоров российских университетов способствовали формированию в российских университетах дисциплинарной группы, разделяющей положения вольфианской Altertumswissenschaft и результаты дисциплинарных дискуссий первой трети XIX в. в немецких университетах. Так, в 1830-е гг. в «ручном режиме» были отобраны, образованы и «посажены» на кафедры молодые ученые первые представители новой классической филологии. В редких случаях проводились конкурсы на кафедры, однако не последнюю роль в окончательном принятии решения университетскими корпорациями играли рекомендации как немецких, так и российских филологов-классиков, направляемые попечителям учебных округов и лично С.С. Уварову. В 1830-1840-е гг. финансируемые государством зарубежные стажировки, а также самостоятельные ученые путешествия были неотъемлемой частью образования и карьеры будущих профессоров-классиков. Сопоставимый образовательный фундамент «новых» профессоров означал сходное понимание содержания классической филологии, методов ее преподавания и исследования. Изменение политических ориентиров государства и изоляция ученых в конце $1840-x$ - начале 1850-х гг. стимулировали формирование горизонтальных связей между филологамиклассиками империи. В это время появился первый совместный проект ученых-классиков (под редакцией П. Леонтьева за пять лет вышло пять томов сборника «Пропилеи»), а страницы толстых журналов стали площадкой для академических дискуссий, в том числе и по 
вопросам классической филологии. Складыванию горизонтальных связей в сообществе способствовали переезды и академическая мобильность филологов-классиков внутри империи, связанная как с изменением должности и места службы, так и с научными командировками.

\section{ПРИМЕЧАНИЯ}

${ }^{1}$ Статья подготовлена в результате проведения исследования в рамках Программы фундаментальных исследований Национального исследовательского университета «Высшая школа экономики» (НИУ ВШЭ) и с использованием средств субсидии в рамках государственной поддержки ведущих университетов Российской Федерации «Проект "5-100"»).

The article was prepared within the framework of the HSE University Basic Research Program and funded by the Russian Academic Excellence Project "5-100".

${ }^{2}$ Благодарю за перевод писем Ф. Фрейтага с немецкого языка на русский Александра Каплуновского.

\section{СПИСОК СОКРАЩЕНИЙ}

ГА РТ - Государственный архив Республики Татарстан.

ГАК - Государственный архив г. Киева.

РГИА - Российский государственный исторический архив.

ЦГАМ - Центральный государственный архив города Москвы.

ЦГИА СПб - Центральный государственный исторический архив Санкт-Петербурга.

ЦГИАК Украины - Центральный государственный исторический архив Украины (г. Киев).

\section{СПИСОК ЛИТЕРАТУРЫ}

1. Биографический словарь профессоров и преподавателей императорского Московского университета за истекающее столетие со дня учреждения января 12-го 1755 года по день столетнего юбилея января 12-го 1855 года, составленный трудами профессоров и преподавателей, занимавших кафедры в 1854 г., и расположенный по азбучному порядку. В 2 ч. Ч. 1. - М. : Унив. тип., 1855. - ХХ, [6], 485 с.

2. Ведомости о занятиях воспитанников Профессорского института за 1828-1832 // РГИА. Ф. 733. - Оп. 56. - Д. 656. - 117 л.
3. Вейсман, А. Д. Успехи греческого языка и литературы в России за последнее двадцатипятилетие / А. Д. Вейсман // Русский вестник. - 1880. № 4. - С. 434- 466 .

4. Виттекер, Ц. Х. Граф Сергей Семенович Уваров и его время / Ц. Х. Виттекер. - СПб. : Акад. проект, 1999. - $352 \mathrm{c}$.

5. Графтон, Э. От полигистора к филологу (как преобразилась немецкая наука об античности в 1780-1850-е гг.) /Э. Графтон// НЛО. - 2006. - № 82. Электрон. текстовые дан. - Режим доступа: http:// magazines.russ.ru/nlo/2006/82/gr4.html (дата обращения: 29.01.2020). - Загл. с экрана.

6. Дела о преобразовании университета по новому уставу, об увольнении и назначении профессоров, о распределении кафедр, увеличении числа помощников инспектора студентов и библиотекаря // РГИА. - Ф. 733. - Оп. 49. - Д. 1004. - 364 л.

7. Дело о доставлении командированных в Берлин воспитанников Профессорского института и их руководителем проф. А.И. Кранихфельдом отчетных сведений о проводимых занятиях // РГИА. Ф. 733. - Оп. 56. - Д. 675. - 202 л.

8. Дело о зачете помощнику библиотекаря эрмитажной библиотеки Ф.Ф. Фрейтагу времени службы его в Дерптском университете и Профессорском институте при нем // РГИА. - Ф. 733. Оп. 24. - Д. 5. - 14 л.

9. Дело о награждении чинами и денежными суммами профессоров Дерптского университета, принимавших деятельное участие в преподавании воспитанникам Профессорского института // РГИА. - Ф. 733. - Оп. 57. - Д. 80. - 64 л.

10. Дело о назначении пенсии ординарному профессору университета Ф.К. Фрейтагу, увольнении его из университета и Главного педагогического института и назначении адъюнкта Главного педагогического института И. Штейнмана экстраординарным профессором института // РГИА. Ф. 733. - Оп. 25. - Д. 140.

11. Дело об объявлении конкурса на занятие кафедр греческой и латинской словесности, в связи со смертью профессора Виленского университета Минниха, о поручении преподавания греческой словесности С.И. Жуковскому, латинской С.К. Гриневичу и о назначении на эту кафедру доктора Риттера // РГИА. - Ф. 733. - Оп. 62. - Д. 1030. - 207 л.

12. Ильина, К. А. Фридрих Фатер и Карл Гофман: филологи-классики из немецких университетов в России в середине XIX в. / К. А. Ильина // Сад ученых наслаждений : сб. тр. ИГИТИ к юбилею проф. И.М. Савельевой. - М. : ИДВШЭ, 2017. -С. 171-182.

13. Историко-филологический факультет Харьковского университета за первые 100 лет его существования (1805-1905). - Харьков : Тип. Адольфа Дарpe, 1908. - VIII, 168, 390, XII c. 
14. Костина, Т. В. Профессора «старые» и «новые»: «антиколлегиальная реформа» С.С. Уварова / Т. В. Костина // Сословие русских профессоров. Создатели статусов и смыслов. - М. : ИД ВШЭ, 2013. - C. 212-238.

15. Мост, Г. Век столкновений: как немецкие антиковеды ХІХ столетия упорядочивали свои дебаты / Г. Мост // НЛО. - 2009. - № 96. - Электрон. текстовые дан. - Режим доступа: http:// magazines.russ.ru/nlo/2009/96/gl5.html (дата бращения: 29.01.2020). - Загл. с экрана.

16. О представлении доктора Гофмана во внимание высшего начальства // ЦГАМ. - Ф. 418. Оп. 7.- Д. 109. -6 л.

17. О службе ординарного профессора латинской словесности Фрейтага // ЦГИА СПб. - Ф. 13.Оп. 1. - Д. 3986. - 10 л.

18. Об избрании и утверждении адъюнкта Дёллена в должность экстраординарного профессора римской словесности и древностей и увольнении Гриневича от звания преподавателя по сей кафедpe// ГАК. - Ф. 16. - Оп. 279. - Д. 241. - 14 л.

19. Об избрании магистра Клеотильда Тхоржевского в адъюнкты Казанского университета // ГА РТ. - Ф. 977. - Оп. Совет. - Д. 2838. - 67 л.

20. Об утверждении адъюнкта университета Св. Владимира Дёллена экстраординарным профессором по кафедре римской словесности и древностей и об увольнении от звания преподавателя по сей кафедре Гриневича // ЦГИАК Украины. Ф. 707. - Оп. 6. - Д. 265.

21. Об утверждении экстраординарным профессором Гофмана // ЦГАМ. - Ф. 418. - Оп. 10. Д. $48 .-3$ л.

22. Обзор деятельности императорского Дерптского университета на память о 1802-1865 гг.: составлен по отчетам и донесениям, представленным попечителю Дерптского учебного округа. - Дерпт : Тип. К. Матисена, 1866. - 172 с.

23. Петров, Ф. А. Формирование системы университетского образования в России. В 4 т. Т. 4. Российские университеты и люди 1840-х гг. Ч. 1. Профессура / Ф. А. Петров. - М. : Изд-во Моск. ун-та, 2003. $-584 \mathrm{c}$.

24. По прошению профессора Одесского лицея Фрейтага об определении его в Киевский университет // ГАК. - Ф. 16. - Оп. 276. - Д. 481. - 17 л.

25. Сборник постановлений по Министерству народного просвещения. В 17 т. Т. 1. Царствование императора Александра I, 1802-1825. - СПб. : [б. и.], 1873. -1864 стб., 43 с., 44 стб.

26. Сборник постановлений по Министерству народного просвещения. В 17 т. Т. 3. Царствование императора Александра II, 1855-1864. - СПб. : [б. и.], 1865. - 1434 стб., 140 с., 42 стб.
27. Сборник распоряжений по Министерству народного просвещения. В 16 т. Т. 2. 1835-1849. СПб. : [б. и.], 1866. - 1104 стб., 74 с., 58 стб.

28. Смышляева, В. П. Российские филологиклассики XIX в.: «германовское» направление : (Материалы для биографического словаря)/ В. П. Смышляева. - СПб. : Лема, 2015. - 535 с.

29. Тернер, Р. С. Историзм, критический метод и прусская профессура с 1740 по 1840 год / Р. С. Тернер // НЛО. - 2006. - № 82. -Электрон. текстовые дан. - Режим доступа: http://magazines.russ.ru/nlo/ 2006/82/te3.html (дата обращения: 29.01.2020). - Загл. с экрана.

30. Тронский, И. М. Из истории классической филологии в России. Споры о школьном произношении древнегреческого языка / И. М. Тронский // Двойной портрет IV. Константы русской культуры : Классический греческий язык и эллинский мир. Эллинисты : Языковеды и педагоги. - М. : Филоматис, 2014. - С. 119-125.

31. Тротман-Валлер, С. Филология вещей или филология слов? История одного спора и его сегодняшние продолжения / С. ТротманВаллер // НЛО. - 2009. - № 96. - Электрон. текстовые дан. - Режим доступа: http:// magazines.russ.ru/nlo/2009/96/se6.html (дата обращения: 29.01.2020). - Загл. с экрана.

32. Уваров, С. С. Десятилетие Министерства народного просвещения. 1833-1843 / С. С. Уваров // Избранные труды. - М. : Рос. полит. энцикл., 2009. - С. 346-455.

33. Фролов, Э. Д. Граф Сергей Семенович Уваров и академический классицизм / Э. Д. Фролов // Петербургская академия наук в истории академий мира: к 275-летию Академии наук. Т. 2 : материалы Междунар. конф. (Санкт-Петербург, 28 июня - 4 июля 1999 г.). - СПб. : С.-Петерб. науч. центр, 1999. - С. 275-285.

34. Фролов, Э. Д. Русская наука об античности / Э. Д. Фролов. - СПб. : Изд-во СПбГУ, 1999. $544 \mathrm{c}$.

35. Штейнман, И. Б. Значение древней филологии и место, которое она занимает в кругу наук, преподаваемых в университетах / И. Б. Штейнман // Журнал Министерства народного просвещения. - 1851. - Ч. 72, отд. 2. - С. 178-200.

36. Юдин, А. В. «Историографические эпохи» в истории изучения античности / А. В. Юдин // Диалог со временем. - 2009. - № 28. - С. 240-262.

37. Album academicum der Kaiserlichen universität Dorpat. - Dorpat : [s. n.], 1889. - 1005 S.

38. Ilina, K. German Classical Philologists at Russian Universities in the 1840 s -1850 s / K. Ilina // History of Education \& Children's Literature. 2017. - Vol. 12, № 2. - P. 263-277. 


\section{REFERENCES}

1. Biograficheskiy slovar professorov $i$ prepodavateley imperatorskogo Moskovskogo universiteta za istekayushchee stoletie so dnya uchrezhdeniya yanvarya 12-go 1755 goda po den stoletnego yubileya yanvarya 12-go 1855 goda, sostavlennyy trudami professorov i prepodavateley, zanimavshikh kafedry v $1854 \mathrm{~g}$., i raspolozhennyy po azbuchnomu poryadku. V2 ch. Ch. 1. [Biographical Dictionary of Professors and Teachers of Imperial Moscow University. 1755-1855. Compiled by Professors and Teachers Who Worked for the Department in 1854 and Arranged in Alphabetical Order. In 2 Parts. Part 1]. Moscow, Universitetskaya tipografiya, 1855. XX, [6], $485 \mathrm{p}$.

2. Vedomosti o zanyatiyakh vospitannikov Professorskogo instituta za 1828-1832 [Class Records of Students of Professorial Institute for 1828-1832]. $R G I A$ [Russian State Historical Archive], F. 733, Op. 56, D. 656. 1171.

3. Veysman A.D. Uspekhi grecheskogo yazyka i literatury v Rossii za poslednee dvadtsatipyatiletie [The Success of the Greek Language and Literature in Russia Over the Last Twenty-Five Years]. Russkiy vestnik, 1880, no. 4, pp. 434-466.

4. Whittaker C.H. Graf Sergey Semenovich Uvarov i ego vremya [Count Sergey Uvarov and His Time]. Saint Petersburg, Akademicheskiy proekt, 1999.352 p.

5. Grafton A. Ot poligistora k filologu (kak preobrazilas nemetskaya nauka ob antichnosti v 1780 1850-e gg.) [Polyhistor into Philolog: Notes on the Transformation of German Classical Scholarship, 1780 - 1850]. NLO [Russian Studies in Literature], 2006, no. 82. URL: http://magazines.russ.ru/nlo/2006/82/ gr4.html (accessed 29 January 2020).

6. Dela o preobrazovanii universiteta po novomu ustavu, ob uvolnenii i naznachenii professorov, o raspredelenii kafedr, uvelichenii chisla pomoshchnikov inspektora studentov i bibliotekarya [Files on the Transformation of the University Under the New Charter, on the Dismissal and Appointment of Professors, on the Allocation of Departments, an Increase in the Number of Assistant Inspectors of Students and a Librarian]. RGIA [Russian State Historical Archive], F. 733, Op. 49, D. 1004. 3641.

7. Delo o dostavlenii komandirovannykh v Berlin vospitannikov Professorskogo instituta $\mathrm{i}$ ikh rukovoditelem prof. A.I. Kranikhfeldom otchetnykh svedeniy o provodimykh zanyatiyakh [File of the Delivery of Students of Professorial Institute and Information on Classes Reported by Their Leader Prof. A.I. Kranichfeld]. RGIA [Russian State Historical Archive], F. 733, Op. 56, D. 675. 2021.

8. Delo o zachete pomoshchniku bibliotekarya ermitazhnoy biblioteki F.F. Freytagu vremeni sluzhby ego v Derptskom universitete i Professorskom institute pri nem [File on Accounting to Assistant Librarian of the Hermitage Library F.F. Freytag of the Period of His Service at University of Dorpat and Professorial Institute Under Him]. RGIA [Russian State Historical Archive], F. 733, Op. 24, D. 5.141.

9. Delo o nagrazhdenii chinami i denezhnymi summami professorov Derptskogo universiteta, prinimavshikh deyatelnoe uchastie $\mathrm{v}$ prepodavanii vospitannikam Professorskogo instituta [File on Rewarding with Ranks and Sums of Money Professors of University of Dorpat, Who Took an Active Part in Teaching the Students of Professorial Institute]. RGIA [Russian State Historical Archive], F. 733, Op. 57, D. 80.641.

10. Delo o naznachenii pensii ordinarnomu professoru universiteta F.K. Freytagu, uvolnenii ego iz universiteta i Glavnogo pedagogicheskogo instituta i naznachenii adyyunkta Glavnogo pedagogicheskogo instituta I. Shteynmana ekstraordinarnym professorom instituta [File on Appointing a Pension to Ordinary Professor of the University F.K. Freytag, Dismissing Him from the University and Main Pedagogical Institute and Appointing Adjunct of Main Pedagogical Institute I. Steynman as an Extraordinary Professor of the Institute]. RGIA [Russian State Historical Archive], F. 733, Op. 25, D. 140.

11. Delo ob obyyavlenii konkursa na zanyatie kafedr grecheskoy i latinskoy slovesnosti, v svyazi so smertyu professora Vilenskogo universiteta Minnikha, o poruchenii prepodavaniya grecheskoy slovesnosti S.I. Zhukovskomu, latinskoy S.K. Grinevichu i o naznachenii na etu kafedru doktora Rittera [File of the Announcement of a Competition for the Work at the Departments of Greek and Latin Literature in Connection with the Death of Professor of Vilnius University Minnich, on the Assignment of Teaching Greek Literature to S.I. Zhukovskiy, Latin Literatureto S.K. Grinevich and on the Appointment of Dr. Ritter to This Department]. RGIA [Russian State Historical Archive], F. 733, Op. 62, D. 1030. 2071.

12. Ilina K.A. Fridrikh Fater i Karl Gofman: filologiklassiki iz nemetskikh universitetov v Rossii v seredine XIX v. [Friedrich Vater and Karl Hoffmann: Classic Philologists from German Universities in Russia in the Middle of the $19^{\text {th }}$ Century]. Sad uchenykh naslazhdeniy: sb. tr. IGITI $k$ yubileyu prof. I.M. Savelyevoy [Garden of Academic Delights. Collection of Works of the Institute of Humanitarian Historical and Theoretical Research to the Anniversary of Prof. I.M. Savelyeva]. Moscow, ID VShE, 2017, pp. 171-182.

13. Istoriko-filologicheskiy fakultet Kharkovskogo universiteta za pervye 100 let ego sushchestvovaniya (1805-1905) [Historical and Philological Faculty of Kharkiv University During the first 100 Years of Its Existence, 1805-1905]. Kharkiv, Tipografiya Adolfa Darre, 1908. VIII, 168, 390, XII p. 
14. Kostina T.V. Professora «starye» i «novye»: «antikollegialnaya reforma» S.S. Uvarova [The "Old" and "New" Professors: "Anti-Collegial Reform" of Sergey Uvarov]. Soslovie russkih professorov. Sozdateli statusov i smyslov [Russian Professors. Makers of Statuses and Meanings]. Moscow, ID VShE, 2013, pp. 212-238.

15. Most G. Vek stolknoveniy: kak nemetskie antikovedy XIX stoletiya uporyadochivali svoi debaty [One Hundred Years of Fractiousness: Disciplining Polemics in Nineteenth-Century German Classical Scholarship]. NLO [Russian Studies in Literature], 2009, no. 96. URL: http://magazines.russ.ru/nlo/2009/ 96/gl5.html (accessed 29 January 2020).

16. O predstavlenii doktora Gofmana vo vnimanie vysshego nachalstva [On the Presentation of Dr. Hoffmann in the Attention of Senior Management]. Ts GAM [Central State Archive of Moscow], F. 418, Op. 7, D. 109. 61 .

17. O sluzhbe ordinarnogo professora latinskoy slovesnosti Freytaga [About the Service of Ordinary Professor of Latin Literature Freitag]. TsGIA $S P b$ [Central State Historical Archive of Saint Petersburg], F. 13, Op. 1, D. 3986. 101.

18. Ob izbranii i utverzhdenii adyyunkta Dellena v dolzhnost ekstraordinarnogo professora rimskoy slovesnosti i drevnostey i uvolnenii Grinevicha ot zvaniya prepodavatelya po sey kafedre [On the Election and Approval of Adjunct Dollen as an Extraordinary Professor of Roman Literature and Antiquities and the Dismissal of Grinevich]. GAK [State Arhive of Kiev], F. 16, Op. 279, D. 241. 141.

19. Ob izbranii magistra Kleotilda Tkhorzhevskogo v adyyunkty Kazanskogo universiteta [On the Election of Master Cleotild Tkhorzhevsky as an Adjunct of Kazan University]. GA RT [State Archive of the Republic of Tatarstan], F. 977, Op. Sovet, D. 2838. 671.

20. Ob utverzhdenii adyyunkta universiteta Sv. Vladimira Dellena ekstraordinarnym professorom po kafedre rimskoy slovesnosti i drevnostey i ob uvolnenii ot zvaniya prepodavatelya po sey kafedre Grinevicha [On the Approval of Adjunct of the University of St. Vladimir Dцllen as an Extraordinary Professor on the Department of Roman Literature and Antiquities and on the Dismissal of Grinevich from the Title of Teacher on This Department]. Ts GIAK Ukrainy [Central State Historical Archive of Ukraine in Kiev], F. 707, Op. 6, D. 265.

21. Ob utverzhdenii ekstraordinarnym professorom Gofmana [On the Approval of Hoffmann as an Extraordinary Professor]. TSGAM [Central State Archive of Moscow], F. 418, Op. 10, D. 48.31.

22. Obzor deyatelnosti imperatorskogo Derptskogo universiteta na pamyat o 1802-1865 gg.: sostavlen po otchetam i doneseniyam, predstavlennym popechitelyu Derptskogo uchebnogo okruga
[Overview of the Activities of Imperial University of Dorpat in Memory of 1802-1865. Compiled from Reports Submitted to the Trustee of the Dorpat School District]. Dorpat, Tipografiya K. Matisena, 1866. 172 p.

23. Petrov F.A. Formirovanie sistemy universitetskogo obrazovaniya $v$ Rossii. $V 4 t$. T. 4. Rossiyskie universitety $i$ lyudi 1840-kh gg. Ch. 1. Professura [Formation of the System of University Education in Russia. In 4 Vols. Vol. 4. Russian Universities and People of the 1840s. Part 1. Professorship]. Moscow, Izd-vo Moskovskogo universiteta, 2003. 584 p.

24. Po prosheniyu professora Odesskogo litseya Freytaga ob opredelenii ego v Kievskiy universitet [On the Request of a Professor of Odessa Lyceum Freitag to Allocate Him at Kiev University]. GAK [State Arhive of Kiev], F. 16, Op. 276, D. 481. 171.

25. Sbornik postanovleniy po Ministerstvu narodnogo prosveshcheniya. $V \quad 17$ t. T. 1. Tsarstvovanie imperatora Aleksandra I, 1802-1825 [Collection of Decisions on the Ministry of Public Education. In 17 Vols. Vol. 1. Reign of Emperor Alexander I, 1802-1825]. Saint Petersburg, [s.n.], 1873. 1864 cols., 43 p., 44 cols.

26. Sbornik postanovleniy po Ministerstvu narodnogo prosveshcheniya. $V \quad 17$ t. T. 3. Tsarstvovanie imperatora Aleksandra II, 1855-1864 [Collection of Decisions on the Ministry of Public Education. In 17 Vols. Vol. 3. Reign of Emperor Alexander II, 1855-1864]. Saint Petersburg, [s.n.], 1865. 1434 cols., 140 p., 42 cols.

27. Sbornik rasporyazheniy po Ministerstvu narodnogo prosveshcheniya. V16 t. T. 2. 1835-1849 [Collection of Decisions on the Ministry of Public Education. In 16 Vols. Vol. 2. 1835-1849]. Saint Petersburg, [s.n.], 1866. 1104 cols., 74 p., 58 cols.

28. Smyshlyaeva V.P. Rossiyskie filologi-klassiki XIX v.: "germanovskoe» napravlenie: (Materialy dlya biograficheskogo slovarya) [Russian Classical Philologists of the $19^{\text {th }}$ Century: "Hermann's" Direction (Materials for a Biographical Dictionary)]. Saint Petersburg, Lema Publ., 2015. 535 p.

29. Turner R.S. Istorizm, kriticheskiy metod i prusskaya professura s 1740 po 1840 god [Historicism, Kritik, and the Prussian Professoriate, 1790 to 1840 ]. $N L O$ [Russian Studies in Literature], 2006, no. 82. URL: http://magazines.russ.ru/nlo/2006/82/te3.html (accessed 29 January 2020).

30. Tronskiy I.M. Iz istorii klassicheskoy filologii v Rossii. Spory o shkolnom proiznoshenii drevnegrecheskogo yazyka [From the History of Classical Philology in Russia. Debate About School Pronunciation of the Greek Language]. Dvoynoy portret IV. Konstanty russkoy kultury: Klassicheskiy grecheskiy yazyk i ellinskiy mir. Ellinisty: Yazykovedy $i$ pedagogi [Double Portrait IV. The Constants of 
Russian culture. Classical Greek and Hellenistic World. The Hellenists. Linguists and Educators]. Moscow, Filomatis Publ., 2014, pp. 119-125.

31. Trautmann-Waller S. Filologiya veshchey ili filologiya slov? Istoriya odnogo spora i ego segodnyashnie prodolzheniya [Philology of Things or Philology of Words? The History of One Dispute and Its Contemporary Continuation]. $N L O$ [Russian Studies in Literature], 2009, no. 96. URL: http://magazines.russ.ru/ nlo/2009/96/se6.html (accessed 29 January 2020).

32. Uvarov S.S Desyatiletie Ministerstva narodnogo prosveshcheniya. 1833-1843 [The Decade of the Ministry of Education]. Izbrannye trudy [Selected Works], Moscow, Rossiyskaiya politicheskaya entsiklopediya Publ., 2009, pp. 346-455.

33. Frolov E.D. Graf Sergey Semenovich Uvarov i akademicheskiy klassitsizm [Count Sergey Uvarov and Academic Classicism]. Peterburgskaya akademiya nauk $v$ istorii akademiy mira: $k$ 275-letiyu Akademii nauk. T. 2: materialy Mezhdunar. konf. (Sankt-Peterburg, 28 iyunya - 4 iyulya 1999 g.) [Petersburg Academy of Sciences in the History of the Academies of the World: To the $275^{\text {th }}$ Anniversary of the Academy of Sciences. Vol. 2. Proceedings of the International Conference (Saint Petersburg, June 28 July 4, 1999)]. Saint Petersburg, 1999, pp. 275-285.

34. Frolov E.D. Russkaya nauka ob antichnosti [Russian Antiquity Studies]. Saint Petersburg, Izd-vo SPbGU, 1999. 544 p.

35. Shteynman I.B. Znachenie drevney filologii i mesto, kotoroe ona zanimaet $\mathrm{v}$ krugu nauk, prepodavaemykh $\mathrm{v}$ universitetakh [Value of Ancient Philology and the Place It Occupies Among Sciences Taught at Universities]. Zhurnal Ministerstva narodnogo prosveshcheniya [Journal of the Ministry of Public Education], 1851, part 72 (2), pp. 178-200.

36. Yudin A.V. «Istoriograficheskie epokhi»v istorii izucheniya antichnosti ["Historiographical Epochs" in Ancient Studies]. Dialog so vremenem [Dialogue with Time], 2009, no. 28, pp. 240-262.

37. Album academicum der Kaiserlichen universität Dorpat. Dorpat, [s. n.], 1889.1005 S.

38. Ilina K. German Classical Philologists at Russian Universities in the 1840s - 1850s. History of Education \& Children's Literature, 2017, vol. 12, no. 2, pp. 263-277.

\section{Information About the Author}

Kira A. Ilina, Candidate of Sciences (History), Leading Researcher, Poletayev Institute for Theoretical and Historical Studies in the Humanities, National Research University "Higher School of Economics", Myasnitskaya St., 20, 101000 Moscow, Russian Federation, glukist@mail.ru, https://orcid.org/0000-0003-3722-6209

\section{Информация об авторе}

Кира Андреевна Ильина, кандидат исторических наук, ведущий научный сотрудник Института гуманитарных историко-теоретических исследований им. А.В. Полетаева, Национальный исследовательский университет «Высшая школа экономики», ул. Мясницкая, 20, 101000 г. Москва, Российская Федерация, glukist@mail.ru, https://orcid.org/0000-0003-3722-6209 